\title{
Examination of morbidity and mortality of cases according to intra-vehicle position and accident mechanism
}

\author{
Orhan Meral, M.D., ${ }^{1}$ Ekin Özgür Aktaş, M.D., ${ }^{2}$ Murat Ersel, M.D. ${ }^{3}$ \\ ${ }^{1}$ Department of Forensic Medicine, Health Sciences University Bozyaka Training and Research Hospital, Izmir-Turkey \\ ${ }^{2}$ Department of Forensic Medicine, Ege University Faculty of Medicine, Izmir-Turkey \\ ${ }^{3}$ Department of Emergency Medicine, Ege University Faculty of Medicine, Izmir-Turkey
}

\begin{abstract}
BACKGROUND: Traffic accidents are still an important public health issue in our country and intra-vehicle accidents cause substantial morbidity and mortality. In this study, we aimed to investigate the effect of seating position on morbidity and mortality in traffic accidents.

METHODS: Patients who were admitted to the Emergency Department, Faculty of Medicine, Ege University between May I, 2014 and November 30, 2014 due to injuries in motor vehicles and who signed informed consent were included.

RESULTS: In total, 519 cases were included, and 329 (63.4\%) were male and 190 (36.6\%) were female. The average age was $33.1 \mathrm{I} \pm \mathrm{I} 6.86$ (range, 0-85) years. It was noted that the accidents most frequently occurred between I8.00 and 23.59 (36.3\%) hours, in the car (79\%), and due to collision with another car (61.7\%). Although $39.5 \%$ of the injured individuals were drivers, $26.4 \%$ were front seat passengers. From a forensic medicine perspective, life-threatening injuries were approximately twice more common (37.5\%$13.6 \%$ in accidents with $>110 \mathrm{~km} / \mathrm{h}$ speed compared with accidents with $<110 \mathrm{~km} / \mathrm{h}$ speed. Accidents with $>110 \mathrm{~km} / \mathrm{h}$ speed caused approximately twice the amount $(56.3 \%-26.3 \%)$ of injuries that cannot be resolved with simple medical intervention compared with accidents with $<110 \mathrm{~km} / \mathrm{h}$ speed.
\end{abstract}

CONCLUSION: Since most people who are injured or die in traffic accidents have an active professional life, significant rehabilitation expenditure and labor loss occur along with diagnosis and treatment costs. Our study and similar studies not only show the effectiveness of the measures taken but also provide an insight into changing injury profiles and precautions to prevent them.

Keywords: Intra-vehicle position; morbidity; mortality; traffic accidents.

\section{INTRODUCTION}

Traffic accidents are among the first in the world among all accidents; ${ }^{[1]}$ deaths due to traffic accidents are II th among all deaths and constitute $2.1 \%$ of all deaths. ${ }^{[2]}$ According to the World Health Organization, about I.24 million people lose their lives in traffic accidents every year and between 20 and 50 million people are injured. ${ }^{[3]}$

In this study, we aimed to investigate the association of mortality and morbidity with the intra-vehicle position of patients who suffered from intra-vehicle accident and were admitted to the emergency department.

\section{MATERIALS AND METHODS}

This was a prospective study. Among the 764 patients who suffered from intra-vehicle accident and were admitted to the Emergency Department, Faculty of Medicine, Ege University between May I, 2014 and November 30, 2014, 519 patients participated in the study either voluntarily or by the consent of their relatives because they were children or unconscious.

Cite this article as: Meral O, Aktaş EÖ, Ersel M. Examination of morbidity and mortality of cases according to intra-vehicle position and accident mechanism. Ulus Travma Acil Cerrahi Derg 2018;24:216-223.

Address for correspondence: Orhan Meral, M.D.

İzmir Bozyaka Eğitim ve Araştırma Hastanesi, Saim Çıkrıkçı Cad., No: 59, Karabağlar, İzmir, Turkey.

Tel: +90 232 - 2505050 / 5832 E-mail: orhanmeral@ymail.com

Ulus Travma Acil Cerrahi Derg 2018;24(3):216-223 DOI: 10.5505/tjtes.2017.34662 Submitted: 19.09.2017 Accepted: 17.10.2017 Online: 08.05.2018

Copyright 2018 Turkish Association of Trauma and Emergency Surgery 
Personal characteristics, such as age and sex; the type of vehicle they were in; the intra-vehicle position of the patients; the mechanism, date, and collision speed of accident; and the type of injury were determined. Vehicle and accident data were obtained from information given by the subjects. In addition, forensic medical evaluation of the identified injuries of cases was performed.

\section{Statistical Analysis}

The data were analyzed with the SPSS program (version 18.0). Demographic data were expressed as mean \pm standard deviation and/or percentage.

The comparison values were calculated at $95 \%$ confidence interval. A p-value of $<0.05$ was considered statistically significant.

\section{RESULTS}

Of the 519 cases included in the study, 329 (63.4\%) were male and 190 (36.6\%) were female, and 72 (13.9\%) were children and 447 (86.1\%) were adults. The highest proportion of the accidents occurred in October $(n=67,17.0 \%)$ and June $(n=65,16.5 \%)$ and most frequently in the evening (between 18.00 and 23.59 hours, $n=\mid 43,36.3 \%)$. The demographic data of subjects and accidents are given in Table I.

In this study, it was found that the majority of the cases were drivers $(n=205,39.5 \%)$ followed by the driver-side passengers $(n=137,26.4 \%)$. The intra-vehicle positions of the cases are shown in Table 2.

The total number of accidents was 394 , and it was found that the accidents were mostly in the form of car collision $(n=169$, $42.9 \%$ ) (Table 3), and I 36 of the collisions (40.1\%) were from the front of the car (Fig. I).

At the time of accident, abrasions due to the safety belt were detected in 40 (17.9\%) of the 224 cases who were found to have a safety belt attached to their neck and/or torso and/or the front of the abdomen. Of these cases, 26 (65\%) were drivers, II (27.5\%) were driver-side passengers and three $(7.5 \%)$ were right rear seat passengers. Table 4 shows the sitting positions of the cases, the number of safety belts in the vehicle, the usage of the safety belt, and the abrasions due to safety belts.

There were air cushions in 224 vehicles (56.9\%), no air cushions in 164 vehicles (41.6\%), and the presence of air cushions was unknown in $6(1.5 \%)$ vehicles. At the time of the accident, air pillows of 105 subjects were opened, 33 of them ( $31.4 \%)$ were injured for this reason, and all of these cases were adult $(p<0.01)$.

When we look at the distribution of the injuries from the traffic accidents according to the body regions, it is seen that
Table I. Demographic data

n (\%)

Distribution of child subjects

$\begin{array}{lc}\text { Woman } & 35(48.6) \\ \text { Man } & 37(51.4) \\ \text { Age range of subjects } & 0-85 \\ \text { Mean age of subjects (year) } & 33.11 \pm 16.86 \\ \text { Adult } & 36.83 \pm 14.87 \\ \text { Child } & 9.62 \pm 6.57\end{array}$

Age groups (year)

0-10

II-20

$21-30$

$31-40$

106 (20.4)

$4 \mid-50$

73 (I4.I)

$5 \mathrm{I}-60$

6I-70

7I and over

Distribution of accidents by month

May

June

July

61 (15.5)

August

46 (II.7)

September

57 (14.5)

October

$67(17.0)$

November

$36(9.1)$

Distribution of accidents by hours

00.00-05.59

$67(17.0)$

06.00-11.59

76 (19.3)

$12.00-17.59$

$108(27.4)$

18.00-23.59

$143(36.3)$

Table 2. Subjects' position in the vehicle

\begin{tabular}{lcc}
\hline Position & Number & Percent \\
\hline In the driver's seat & 205 & 39.5 \\
Next to the driver & 137 & 26.4 \\
Rear seat on the right & 55 & 10.6 \\
Rear seat on the left & 48 & 9.2 \\
Other positions & 74 & 14.3 \\
Total & 519 & 100.0 \\
\hline
\end{tabular}

the head is the most frequently injured body part $(n=225$, $43.4 \%)$ and the second and third frequent parts were thorax $(n=114,22 \%)$ and upper extremity $(n=111,21.4 \%)$, respectively. The injury areas of the cases are shown in Figure 2. In 
Table 3. Mechanism of accident occurrence

\begin{tabular}{lcc}
\hline Position & Number & Percent \\
\hline Collision with a car & 169 & 42.9 \\
Collision with pole/tree/refuge & 96 & 24.3 \\
Rolling over & 22 & 5.6 \\
Sudden brake/acceleration & 20 & 5.1 \\
Collision with a minibus & 19 & 4.8 \\
Collision with a camion & 17 & 4.3 \\
Collision with a van & 16 & 4.1 \\
Collision with a truck & 14 & 3.6 \\
Collision with a bus & 8 & 2.0 \\
Skidding & 8 & 2.0 \\
Flying & 5 & 1.3 \\
Total & 394 & 100.0 \\
\hline
\end{tabular}

addition, the analysis of the concomitant injuries is detailed in Table 5.

In our study, the frequency of injuries according to body regions was examined in children and adults. The head injury rate was $56.9 \%$ in the pediatric age group and $41.2 \%$ in the adult group $(p<0.01)$. The incidence of neck injury was $2.8 \%$ in the pediatric age group and $10.3 \%$ in the adult $(p<0.05)$. The incidence of thoracic injuries was $9.7 \%$ in the pediatric age group and $23.9 \%$ in the adult group $(p<0.01)$. Finally, the incidence of upper extremity injuries was $12.5 \%$ in the pediatric age group and $22.8 \%(p<0.05)$ in the adult group. There was no significant difference between the pediatric and adult age groups in the wrist, pelvis, and lower extremity injuries. In addition, it was found that single region injuries were more frequent in children and multiple region injuries in adults $(p<0.01)$.
When the injury regions and the in-car position of the patients were compared, nine of 12 (75\%) children aged between 0 and 5 years who were sitting on the lap were injured in the head region; none of these 12 children and none of the 21 passengers sitting in the middle of the rear seat were injured in the neck region $(p<0.05)$. None of the three children aged between $I$ and 5 years who were sitting in child safety seat were injured, and $91.7 \%$ of the passengers who were sitting on the rear left were not injured in the thorax region. No significant difference was found in other comparisons.

When the region of injury and vehicle collision zones were compared, the rate of thoracic injuries occurring in the front $(21.9 \%)$ and side $(28.8 \%)$ collisions was higher than that of the collisions in the back $(7.4 \%)(p<0.05)$. The distribution of injured body parts according to the collision areas of vehicles is shown in Figure 3.

It was determined that 22 cases applied to the emergency department for the purpose of control, I 5 I cases (30.4\%) of the 497 cases were injured in one region, and 346 cases $(69.6 \%)$ were injured in more than one region. When the number of injured body regions and in-car position were compared, most of the cases that had single-site injuries were drivers $(n=41,27.2 \%)$ or driver-side passengers $(n=39,25.8 \%)$; and most of the patients who had more than one injured region were drivers $(n=160,46.3 \%)$ or driver-side passenger $(n=95$, $27.5 \%)$.

In this study, the injury of $15 \%(n=78)$ of the patients led to vital danger when evaluated from the point of forensic medicine. When the accident speed of the vehicles were classified as below and above $110 \mathrm{~km} / \mathrm{h}$ and the injuries as being treated by simple medical intervention or not and when the injuries were evaluated according to the presence or absence

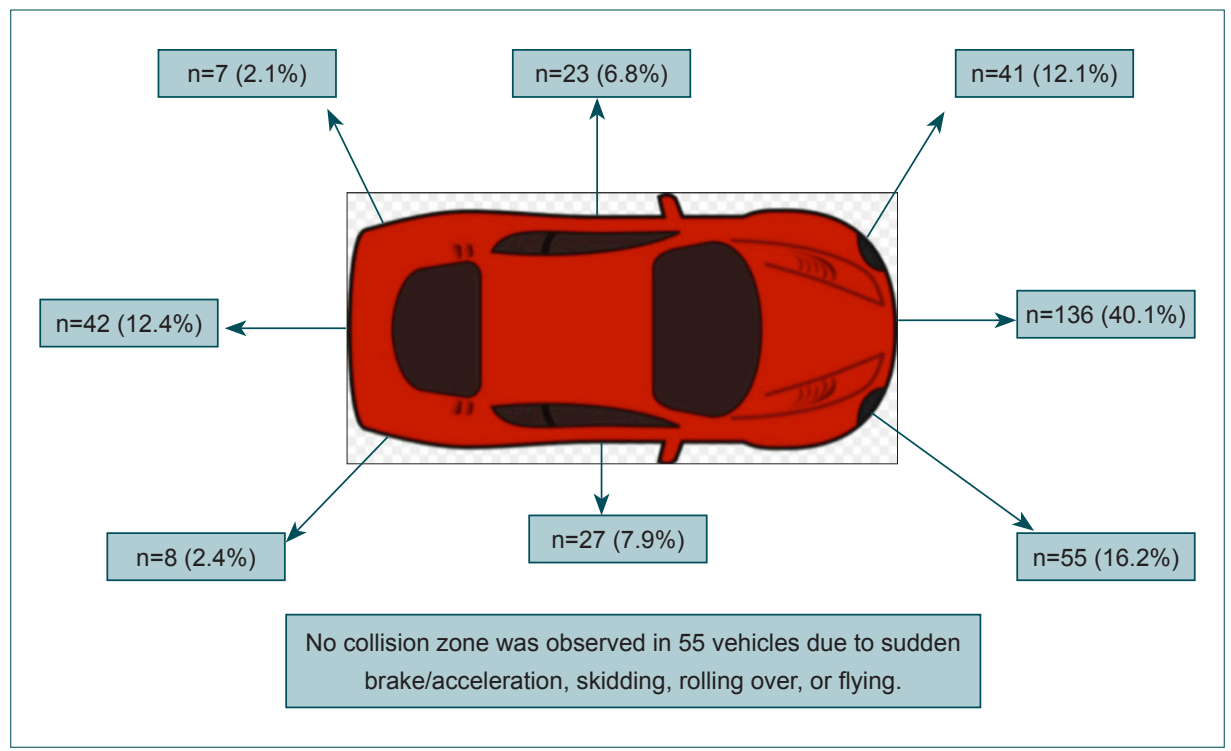

Figure 1. Collision zones. 
Table 4. Safety belt use and lesion incidence

\begin{tabular}{|c|c|c|c|c|c|c|c|}
\hline & Driver & $\begin{array}{l}\text { Next to the } \\
\text { driver }\end{array}$ & $\begin{array}{c}\text { Rear seat } \\
\text { on the right }\end{array}$ & $\begin{array}{l}\text { Rear seat } \\
\text { on the left }\end{array}$ & $\begin{array}{c}\text { Rear seat } \\
\text { in the middle }\end{array}$ & Others & Total \\
\hline \multicolumn{8}{|l|}{ Seatbelt attached } \\
\hline No abrasion & $96(46.8 \%)$ & $60(43.8 \%)$ & 7 (12.7\%) & 14 (29.2\%) & $3(14.3 \%)$ & $4(7.5 \%)$ & I84 (35.5\%) \\
\hline There is abrasion & $26(12.7 \%)$ & II (8\%) & $3(5.5 \%)$ & $0(0 \%)$ & $0(0 \%)$ & $0(\% 0)$ & $40(7.7 \%)$ \\
\hline \multicolumn{8}{|l|}{ Seatbelt not attached } \\
\hline No abrasion & $83(40.5 \%)$ & $66(48.2 \%)$ & 45 (81.8\%) & $34(70.8 \%)$ & I8 (85.7\%) & 49 (92.5\%) & 295 (56.8\%) \\
\hline Total & 205 & 137 & 55 & 48 & 21 & 53 & 519 \\
\hline
\end{tabular}

*The percentages are calculated according to the columns.

Table 5. Co-occurrence of injured areas

\begin{tabular}{|c|c|}
\hline Areas & Number* \\
\hline Head-Thorax & 41 \\
\hline Head-Lower extremity & 32 \\
\hline Head-Upper extremity & 30 \\
\hline Head-Abdomen & 25 \\
\hline Head-Neck & 16 \\
\hline Head-Pelvis & 5 \\
\hline Neck-Thorax & 16 \\
\hline Neck-Abdomen & 7 \\
\hline Neck-Lower extremity & 6 \\
\hline Neck-Upper extremity & 6 \\
\hline Neck-Pelvis & 2 \\
\hline Thorax-Abdomen & 32 \\
\hline Thorax-Upper extremity & 29 \\
\hline Thorax-Lower extremity & 14 \\
\hline Thorax-Pelvis & 7 \\
\hline Abdomen-Upper extremity & II \\
\hline Abdomen-Lower extremity & 9 \\
\hline Abdomen-Pelvis & 7 \\
\hline Pelvis-Upper extremity & 5 \\
\hline Pelvis-Lower extremity & 5 \\
\hline Upper extremity-Lower extremity & 16 \\
\hline
\end{tabular}

*In 346 cases, multiple site injuries were seen, no total number of injuries.

of life-threatening hazard, it was observed that the increase in speed resulted in tripling of the number of life-threatening injuries (13.6\%-37.5\%) and doubling of the number of injuries that could not be treated by simple medical intervention $(26.3 \%-56.3 \%)$. These findings were found to be statistically significant $(p<0.01)$.

It was observed that 444 patients $(85.5 \%)$ were discharged after interventions in the emergency department, and seven patients (1.4\%) did not admit the recommended follow-up

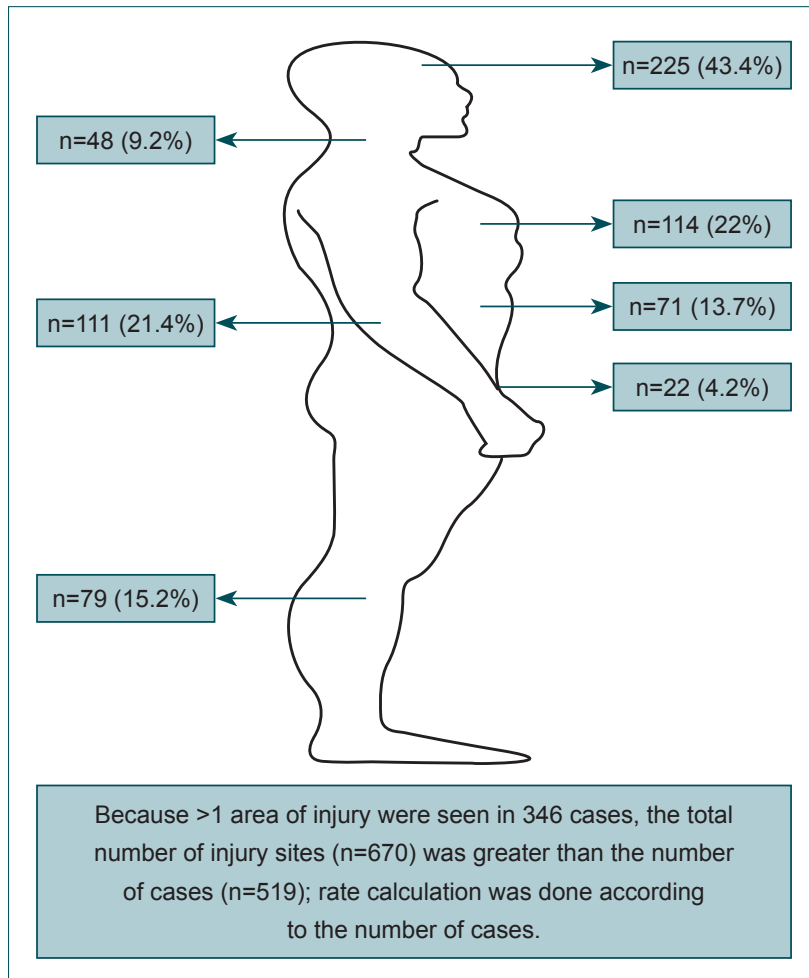

Figure 2. Distribution of injury areas.

and treatment and left the emergency department. Of the patients admitted to the emergency department, four $(0.8 \%)$ died and 64 (12.3\%) were admitted to the related clinics. Of the patients admitted to clinics, $6 \mathrm{I}$ (95.3\%) were discharged and three $(4.7 \%)$ died. Among the victims, three were drivers, two were driver-side passengers, and the other two were children who sat in the lap. It was noted that none of the victims were wearing their safety belts during the accident, and only one of them had an air pillow.

\section{DISCUSSION}

Traffic accidents constitute a significant part of the admissions made to emergency departments. ${ }^{[4]}$ Similar to what we found in our study (male $=63.4 \%$ ), it is reported that most of the victims of deaths in traffic accidents around the world 


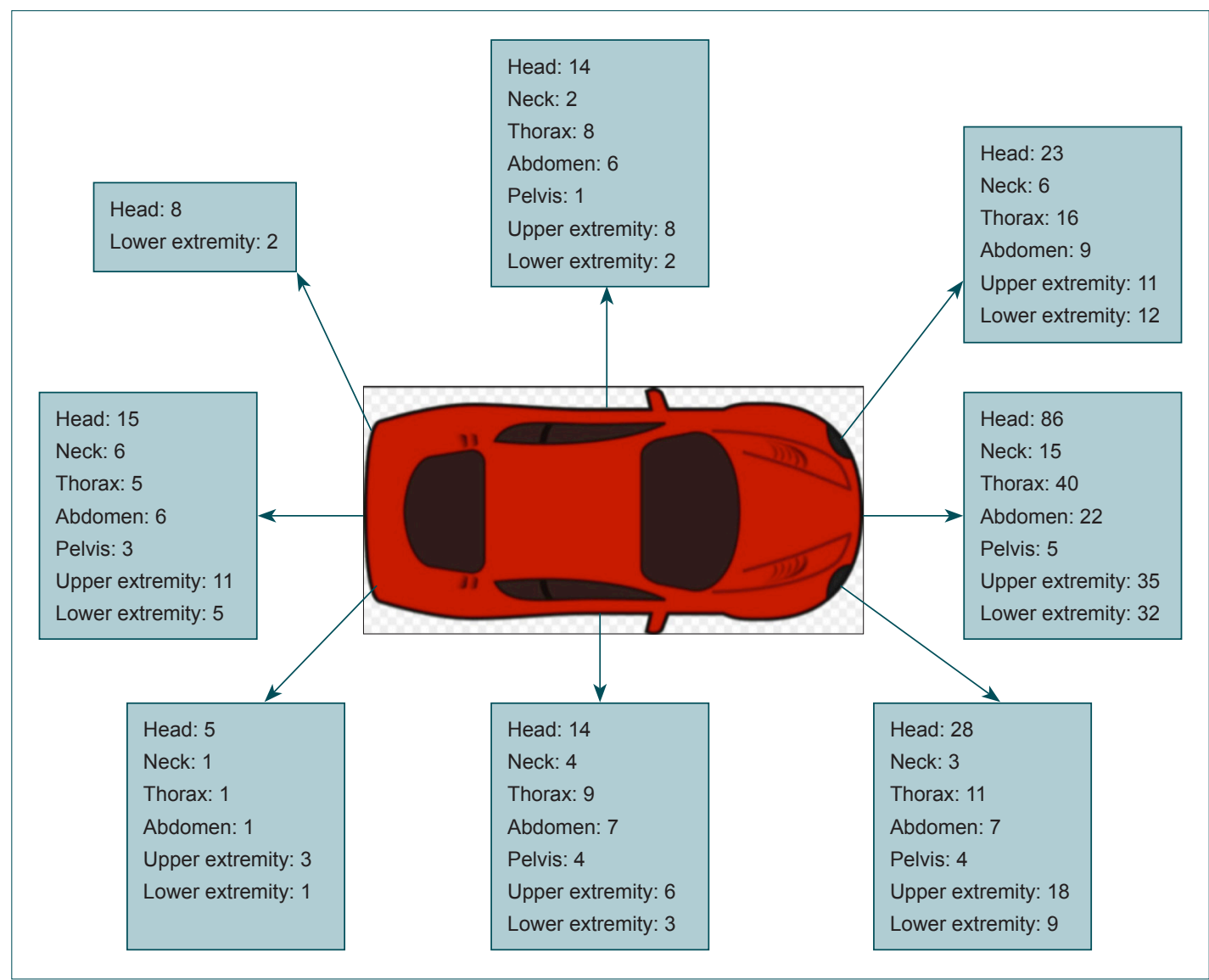

Figure 3. Distribution of injured body parts according to vehicle collision areas.

are male. ${ }^{[5-7]}$ The mean age of the cases was found to be $33.11 \pm 16.86$ and injuries due to traffic accidents were found to be the most frequent in the $21-30$-year age group $(n=147$, $28.3 \%)$, and this finding is coherent with many studies. ${ }^{[1,5,7-10]}$ When the studies performed in our country were reviewed, the 30-49-, 30-49-, and 0-14-year age groups were the leading age groups in the study performed by Mandıracıoğlu, ${ }^{[1]}$ Gören, ${ }^{[12]}$ and Varol, ${ }^{[13]}$ respectively.

In our study, it was observed that accidents occurred at a higher rate in October $(n=67,17 \%)$ and June $(n=65,16.5 \%)$. In many studies conducted in our country, accidents have been reported to occur more frequently in summer. ${ }^{[1,4,7,12,14]}$ It is thought that this is due to the excessive number of travelers due to summer holidays and because people drive more carefully by considering the weather condition and traffic intensity during the winter months.

In this study, it was seen that accidents occur frequently between 18.00 and 23.59 hours $(n=143,36.3 \%)$. This ratio was found to be consistent with the large number of studies conducted in our country. ${ }^{[4,7-9,14,15]}$ The frequency of accidents in this time period was considered to be associated with fatigue and inattentiveness of the drivers during work, inadequacy of sunset lighting, and limitation of sight distance.
It was determined that most of the cases detected in the study were drivers $(n=205,39.5 \%)$ and a significant number of cases ( $n=137,26.4 \%$ ) were sitting next to the driver. In Bilgin's study, which was conducted in İzmir, it was reported that drivers and passengers sitting next to the driver are the most frequently injured people in accidents. ${ }^{[5]}$

In this study, there was a collision with another vehicle or barrier in 339 (86\%) of the 394 accidents. In all accidents, car crash ( $n=169,42.9 \%)$ was the leading cause, and I 36 (40.1\%) of the 339 crashes occurred in front of the vehicle they were in. A four-year retrospective study conducted in İzmir ${ }^{[15]}$ and another study that analyzed all of the accidents in Düzce ${ }^{[16]}$ reported that the most common type of accident mechanism was collision.

One of the passive safety measures in the vehicle, the safety belt prevents a passenger from being thrown out of the car due to the impact of the collision, allowing the gradual reduction of the collision in the body and allowing the collision effect to spread rather than accumulate in one spot on the body. ${ }^{[17-19]}$ It was noted that 295 of the cases (56.8\%) were not wearing a seat belt during the accident; $59.2 \%$ of the cases in the study of Bilgin, ${ }^{[5]} 85 \%$ in the study of Karbeyaz ${ }^{[7]}$ and $32.7 \%$ in a foreign study ${ }^{[20]}$ were not wearing safety belts at the time of the accident. 
It is thought that the difference between this study and the other studies is due to the fact that other studies are retrospective and that sufficient information about the cases could not be reached in other studies. According to TURKSTAT's 2013 data, ${ }^{[21]} 85.9 \%$ of the patients involved in accidents in 2013 had worn safety belts. Any sufficient information about the safety belt usage of $95 \%$ of the drivers in these cars could not be reached. The only information that could be obtained was that $2.6 \%$ of the drivers were wearing safety belts during the accident. All of these findings support our thinking. It can be said that the use of the safety belt is not sufficient at present with having limited data. There has also been a lack of access to the availability of safety belts throughout the country and it is considered necessary to increase efforts to disseminate the use of safety belts.

Thus, one of every three passengers with air cushions was injured. All of the injured patients were adults $(p<0.0 \mathrm{I})$ and most injuries ( $n=14,42.4 \%$ ) occurred in the face region. This ratio was found to be quite high, and it is considered that new generation airbags should be produced to reduce the injuries due to airbags and new measures should be taken.

Regarding the distribution of injuries detected in our cases according to body regions, the head $(n=225,33.6 \%)$ was the most common region among single-site injuries, followed by the thorax $(n=\mid 14,17 \%)$ and upper extremity $(n=|1|, 16.5 \%)$. It is notable that head injuries are more frequent in children and that neck, thorax, and upper extremity injuries are more frequent in adults. There are several reasons for head injury in children. First, children are more likely to be seated on the back seat and are not ready for an accident. Second, passive safety measures such as air cushions and seat belts are relatively uncommon in the backseat. Additionally, they would be thrown during the accident in the vehicle because they have shorter body length and greater head/torso ratio compared with adults and due to scattering they may have head trauma as a result of collision with seat, door, and passenger and so on. As adults prefer the front seat, scattering results in injuries to the neck, thorax, and upper extremities, which are more likely to occur primarily due to collision with the steering wheel, front panel, door, and so on in relation to the seating height.

While examining 346 cases in which more than one region injury occurred, it was observed that although the head-thorax association was seen most frequently, the thorax-abdomen, head-lower extremity, and thorax-upper limb associations were also common.

When compared with other studies related to traffic accidents in our country, in studies conducted by Karbeyaz, ${ }^{[7]}$ Serinken, ${ }^{[14]}$ Varol, ${ }^{[13]}$ Bilgin, ${ }^{[5]}$ and Aydeniz, ${ }^{[8]}$ it was observed that head and neck injuries were the second most common injuries following lower extremity injuries. Although our study includes intra-vehicle traffic accidents, in outer vehicle traffic accidents, injured zone changes according to the type of accident are normal when the following facts are considered: first, the number and severity of injuries increases due to the absence of effective safety measures such as safety belts and air cushions in non-vehicular traffic accidents; second, extremity injuries are more frequent in pedestrians; and additionally, the type of associated injury regions differ related to the injury site.

It is stated that the severity of the injury profile and damage differs due to several factors such as the speed and physical characteristics of the vehicle, application of brake during the accident, in-vehicle position of the passengers during the accident, being a child or adult, and whether the accident happened in or out of the car. ${ }^{[22-24]}$ In our study, it was seen that single-site injuries were observed in children and more than one region injuries were seen in adult cases $(p<0.01)$. When the number of injured zones was compared with the in-car position of the cases, drivers and driver-side front passenger injuries from more than one body region were seen more frequently than other passengers and those traveling on public transport and child passengers sitting on the lap had single-site injuries more often compared with other passengers. When these two conditions are evaluated together, it is thought that adults have multiple-site injuries, while children have single-site injuries more commonly because children often travel in the back seat and adults often travel in the front seat.

In our study, no statistically significant difference was found between the severities of injuries due to the position of the injuries in the vehicle $(p>0.05)$. In the international studies, it was stated that the back seat passengers without safety belts were more at risk and injured than the front seat passengers ${ }^{[20,25]}$ and that traveling without a seat belt on the rear seat increases the mortality of the passenger sitting on the front seat by 2.5 times. ${ }^{[26]}$

In this study, it has been determined that 15\% of the injuries have put the life of the victim in jeopardy in terms of forensic medicine. Another study ${ }^{[5]}$ in İzmir showed that $15.3 \%$ of the cases had a life-threatening injury and it was found to be compatible with our findings.

When the cases presented in this study were examined in terms of accident speeds below or above $110 \mathrm{~km} / \mathrm{h}$, whether the injuries could be resolved by simple medical intervention from a forensic medical point of view, and whether there was a life-threatening hazard, it was seen that the life-threatening potential of injury tripled and the likelihood of the injury to resolve with simple medical intervention decreased double times as the speed increased $(p<0.0 \mathrm{l})$; in this case, it is clear that journeys at high speeds are not safe and related to high mortality and morbidity.

Despite medical interventions, four cases died in the emergency department and three in the department where they 
were admitted. Our data are consistent with the study of Aktaş ${ }^{[9]}$ and Bilgin, ${ }^{[5]}$ both of which were conducted in Izmir, and with the study of Emet ${ }^{[27]}$ in Erzurum.

\section{Conclusion and Recommendations}

Our study presents an important cross-section of mechanisms and injury patterns of in-vehicle traffic accidents in Turkey. According to the results obtained, airbags are not found in four out of every 10 cars involved in traffic accident with injury. While $40 \%$ of drivers involved in these accidents did not wear seat belts, the use of seat belts is even lower in the rear seat.

Most of the accidents occurred in the form of frontal collision, and it is determined that head injury is the most common type of injury in all ages, followed by thorax and upper limb injuries. In addition, head injuries were significantly higher in the pediatric age group than in adults.

Traffic accidents in our country are still an important cause of morbidity and mortality. Although the use of safety belts was imperative for drivers and passengers in all vehicle seats on the date of this study, the use of protective equipment appears to be limited. However, we believe that it is wise to focus on the technological precautions that protect the head and chest area to reduce the severity of injuries, since it has been seen that accidents are often the result of collisions with the front and side regions of the vehicle and that drivers and passengers are injured more frequently in the head and thorax region.

In this study, it was clearly revealed that the accidents that occurred at a speed of $110 \mathrm{~km} / \mathrm{h}$ caused more serious injuries. We would like to emphasize that the use of electronic equipment in vehicles that can reduce vehicle speed independently from the driver in the event of a collision may be a matter of reducing morbidity and mortality. We believe that our study, which examines accident mechanism and injury patterns, will possibly help to better analyze accident injury mechanisms and will help take measures in this respect by helping those performing similar studies in larger national databases.

Conflict of interest: None declared.

\section{REFERENCES}

1. Dirlik M, Çakır Bostancıoğlu B, Elbek T, Korkmaz B, Çallak Kallem F, et al, Features of the traffic accidents happened in the province of Aydin between 2005 and 2011. Ulus Travma Acil Cerrahi Derg 2014;20:353-8.

2. Joshi AK, Joshi C, Singh M, Singh V. Road traffic accidents in hilly regions of northern India: What has to be done? World J Emerg Med 2014;5:112-5. [CrossRef]

3. World Health Organization. Global status report on road safety 2013: supporting a decade of action. Available at: apps.who.int/iris/bitstre am/10665/78256/1/9789241564564_eng.pdf. Accessed 3rd May, 2018.
4. Göksu E, Çete Y, Kanalıcı H, Kilıçaslan İ. Demographic and clinical properties of patients presenting with traffic accidents and its association with blood alcohol concentration. Turk J Emerg Med 2008;8:26-31.

5. Bilgin UE, Meral O, Koçak A, Aktaş EÖ, Kıyan S, Altuncı YA. Legal examination of the patients admitted to the Emergency Service of Ege University Hospital due to traffic accidents in 2011 [Article in Turkish]. Ege Journal of Medicine 2013;52:93-9.

6. Conti A, Torino R. Fatal road accidents in Brescia: Comparison between three different periods. International Journal of Risk and Safety in Medicine 2004;16:149-58.

7. Karbeyaz K, Balcı Y, Çolak E, Gündüz T. Charateristics of the traffic accidents in Eskişehir between the years 2002 and 2007. J Foren Med 2009;6:65-73.

8. Aydeniz E, Ünaldı M, Güneysel Ö, Eryiğit H. The Retrospective Evaluation of Injuries Owing to Traffic Collisions in Emergency Department. J Kartal TR 2014;25:5-12. [CrossRef]

9. Aktaş EÖ, Koçak A, Zeyfeoğlu Y, Solak İ, Aksu H. Ege Üniversitesi Tip Fakültesi Adli Tip Anabilim. Dalı́na trafik kazası nedeniyle başvuran adli olguların değerlendirilmesi. Uluslararası Trafik ve. Yol Güvenliği Kongresi. Ankara: 2002.

10. Töro K, Hubay E, Sotonyi P, Keller E. Fatal traffic injuries among pedestrians, bicyclists and motor vehicle occupants. Forensic Sci Int 2005;151:151-6. [CrossRef]

11. Mandıracıoğlu A, Hancı İH, Yavuz C, Aktaş EÖ. İzmir ilinde trafik kazalarında insan faktörü. IV. Ulusal Halk Sağlığı Kongresi Sept 12-16, 1994 Didim. Didim: Bildiriler Kitapçığı; 1994. p. 131-5.

12. Gören S, Subaşı M, Tiraşçı Y, Kaya Z. Deaths related to traffic accidents [Article in Turkish]. J Foren Med 2005;2:9-13.

13. Varol O, Eren ŞH, Oğuztürk H, Korkmaz İ, Beydilli İ. Investigation of the Patients Who Admitted After Traffic Accident to the Emergency Department [Article in Turkish]. C. Ü. Tip Fakültesi Dergisi 2006;28:55-60.

14. Serinken M, Özen M. Characteristics of injuries due to traffic accidents in the pediatric age group [Article in Turkish]. Ulus Travma Acil Cerrahi Derg 2011;17:243-7. [CrossRef]

15. Yavuz C, Mandıracıoğlu A, Hancı İH, Aktaş EÖ. İzmir İlinde Trafik Kazalarında Teknik Boyutu. IV. Ulusal Halk Sağlığı Kongresi Sept 12 16 1994, Didim. Didim: Bildiriler Kitabı; 1994. p. 136-9.

16. Ozgan E. Analysis of the relationship between results of accidents with highways' vehicle type and kinds of the accidents. J Fac Eng Arch Gazi Univ 2008;23:97-104.

17. Elvik R, Vaa T, Hoye A, editors. The Handbook of Road Safety Measures. 2nd ed. Emerald Group Bingley: Publishing Limited; 2009.

18. Shkrum MJ, Ramsay DA. Forensic Pathology of Trauma. Totowa: Humana Press Inc.; 2007.

19. Soysal Z, Eke SM, Çağdır S. Adli Otopsi. Volume I. İstanbul Üniversitesi: Cerrahpaşa Tıp Fakültesi Yayınları; 1999.

20. Brown CK, Cline DM. Factors affecting injury severity to rear-seated occupants in rural motor vehicle crashes. Am J Emerg Med 2001;19:93-8.

21. http://www.tuik.gov.tr/Kitap.do? metod=KitapDetay $\&$ KT ID=15\&KITAP_ID=70. Erişim Tarihi: 03.05.2018.

22. Çetin G, Yorulmaz C. Trafik Kazasına Bağlı Yaralar. Soysal Z, Çakalır C, editors. Adli Tip. 1st ed. Istanbul: Istanbul Üniversitesi Basımevi ve Film Merkezi; 1999.

23. Saukko PJ, Knight B. Knight's forensic pathology. 3rd ed. London: Arnold; 2004.

24. Hancı İH. Adli Tip ve Adli Bilimler. 1st ed. Ankara: Seçkin Yayıncllık; 2002. p. 167-212. 
25. Broughton J. The actual threat posed by unrestrained rear seat car passengers. Accid Anal Prev 2004;36:627-9. [CrossRef]

26. Bose D, Arregui-Dalmases C, Sanchez-Molina D, Velazquez-Ameijide J, Crandall J. Increased risk of driver fatality due to unrestrained rear-seat passengers in severe frontal crashes. Accid Anal Prev 2013;53:100-4.

27. Emet M, Beyhun NE, Özüçelik DN, Fidan V. Patients presenting to a State Hospital with injuries from Motor Vehicle Crash [Article in Turkish]. Turk J Emerg Med 2006;6:149-53.

\section{ORIJINAL ÇALIŞMA - ÖZET}

\section{Araç içi pozisyon ve kaza mekanizmasına göre olguların morbidite ve mortalitesinin incelenmesi \\ Dr. Orhan Meral,, ${ }^{1}$ Dr. Ekin Özgür Aktaş, ${ }^{2}$ Dr. Murat Ersel ${ }^{3}$}

1Sağlık Bilimleri Üniversitesi İzmir Bozyaka Eğitim ve Araştırma Hastanesi, Adli Tıp Bölümü, İzmir

${ }^{2}$ Ege Üniversitesi Tıp Fakültesi, Adli Tıp Anabilim Dalı, İzmir

${ }^{3}$ Ege Üniversitesi Tıp Fakültesi, Acil Tıp Anabilim Dalı, İmir

AMAÇ: Trafik kazaları halen ülkemizde önemli bir halk sağlığı sorunu olup, araç içi trafik kazaları da önemli bir morbidite ve mortalite nedenidir. Bu çalışmada, trafik kazalarında kazazedenin araç içi pozisyonunun morbidite ve mortalite üzerine olan etkisinin araştırılması amaçlandı.

GEREÇ VE YÖNTEM: Ege Üniversitesi Tıp Fakültesi Hastanesi Acil Servisi'ne 0I.05.20।4-30.1 I.20।4 tarihleri arasında araç içi trafik kazası sonucu yaralanma nedeniyle başvuran olgulardan onam verenler çalışmaya dâhil edildi.

BULGULAR: Çalışmaya dâhil edilen 519 olgunun 329'u (\%63.4) erkek, 190'ı (\%36.6) kadındı. Yaşları 0-85 arasında değişmekte olup ortalaması 33.I I I I6.86 olarak bulundu. Kazaların en sık 18.00-23.59 saat aralığında (\%36.3), otomobil içinde (\%79) ve bir başka araçla çarpışma (\%6।.7) sonucu gerçekleştiği tespit edildi. Kazazedelerin \%39.5'inin sürücü, \%26.4'ünün sürücü yanı yolcu olduğu saptanmış olup, II 10 km/sa hızın üzerinde oluşan kazalarda, $110 \mathrm{~km} / \mathrm{sa}$ hızın altında olan kazalara göre, adli tıbbi açıdan, yaralanmanın yaşamsal tehlike oluşturmasıının yaklaşık üç katına (\%37.5-\%|3.6), basit bir tıbbi müdahale ile giderilemeyecek olmasının ise yaklaşık iki katına (\%56.3-\%26.3) çıktı̆ı belirlendi.

TARTIŞMA: Trafik kazalarında yaralanan veya ölen kişilerin çoğunun aktif iş yaşamında olması, tanı ve tedavi giderlerinin yanında ciddi bir rehabilitasyon ve iş gücü kaybı oluşturmaktadır. Bu çalışma ve benzer çalışmalar, alınan önlemlerin etkinliklerini gösterdiği gibi değişen yaralanma profillerinin de anlaşılması ve bunları önlemek için alınacak önlemlere ışık tutması açısından önemlidir.

Anahtar sözcükler: Araç içi pozisyon; morbidite; mortalite; trafik kazası.

Ulus Travma Acil Cerrahi Derg 2018;24(3):216-223 doi: 10.5505/tjtes.2017.34662 